ROCZNIKI HUMANISTYCZNE

Tom LXVIII, zeszyt $11-2020$

DOI: https://doi.org/10.18290/rh206811-9

SILVIA MARTÍNEZ-FALQUINA

\title{
GRIEVING PLACES, SOVEREIGN PLACES: STORIED SPACE IN LOUISE ERDRICH'S THE ROUND HOUSE*
}

\begin{abstract}
A b s t r a c t. This essay makes a contribution to the current conversation on Native American resurgence in the context of settler colonial dispossession and displacement. It responds to the pressing need to overcome simplistic representations of Native Americans and place by acknowledging the essential relationality of identity, articulated as being-with-the-land and grounded normativity. It does so by providing an analysis of Anishinaabe writer Louise Erdrich's The Round House (2012) focused on relevant symbolism, characterization and themes around the re-storying of Native selves and lands that articulate the novel as a decolonial palimpsest made of different but intricately interwoven layers. The essay leads to the conclusion that Erdrich's novel is an act of re-mapping in words that restores agency to Indigenous peoples, re-enfranchises American Indian grief, acknowledges the complex, intricate relation to settler colonial ways, and reformulates sovereignty on its own terms.
\end{abstract}

Keywords: Native American fiction; resurgence; palimpsest; land-as-identity; land-as-relationship.

\section{NATIVE AMERICANS, SETTLER COLONIALISM AND THE LAND}

As Gordon Henry claims in “Anishinaabeskinuk: Writing Over Skins, Writing Over Imagi (natives),

[s]ince the arrival of Europeans and other others on North American shores, the lands, people, languages, stories and songs of Native North Americans tribes have been written

SiLVIA MARTínEZ-FALQUINA is Associate Professor of US Literature at the University of Zaragoza; address for correspondence: Departamento de Filología Inglesa y Alemana, Universidad de Zaragoza, Facultad de Filosofía y Letras, Calle San Juan Bosco, 7, 50009 Zaragoza, Spain; e-mail: smfalqui@unizar.es; ORCID: https://orcid.org/0000-0002-8054-095X.

* The research carried out for the writing of this article is part of a project financed by the Spanish Ministry of Economy, Industry and Competitiveness (MINECO) in collaboration with the European Regional Development Fund (DGI/ERDF) (code FFI2017-84258-P). The author is also thankful for the support of the Government of Aragón and the European Social Fund (ESF) (code H03_20R) as well as the University of Zaragoza and the Ibercaja Social Fund (code JIUZ-2019-HUM-02). 
upon and written over and over again by European, Euro-American, settler-colonial and contemporary post-capitalist explorers, travellers, scholars and writers. (32)

The "layered, continued over-writing of tribal people" (32) that Henry refers to is directly connected to the displacement and destruction brought on by settler colonial processes. Complex and multifarious, one of its most distinct facets is mapping, "an intensely political enterprise, an essential step toward appropriation and possession," for maps "write the conquerors' stories over the stories of the conquered" (Owens 211). In spite of settler colonial efforts to erase the Indigenous peoples and ways from the occupied territories, this overwriting has rather resulted in "a kind of palimpsest" (Breinig 55), a reminder that "what has been excluded can never be erased, but only overwritten by what has been selected. And the traces of the repressed are therefore present and the repressed alternatives can be reconstructed" (Breinig and Lösch 110). In this article I offer an analysis of the Anishinaabe writer Louise Erdrich's The Round House (2012) aimed at uncovering the complex layering that results from acts of settler colonial mapping and Indigenous re-mapping. I will base my reading on the premise, offered by Henry, that it is not only non-Native scholars and writers who write upon and over tribal people, but that American Indian writers also engage in an exercise of interpretive overwriting of Native lives and cultures, and that this derives in "tribally generated, or post-colonial, or de-colonial palimpsests" that aim at the "restoration and re-storying of Native voices in contemporary encounters" (33). This study will thus delve into the intricacy of the settler colonial and decolonial overwriting processes and connect the latter to re-storying acts of Indigenous resistance and resurgence in relation to place.

The space referred to as "the land"- conceived in a broad sense to include the whole natural world, all physical phenomena, living and inanimate beingsis the basic source of individual and communal identity in all Native American tribes. The land provides both physical and spiritual sustenance, and it is essential to issues of tribal sovereignty. In contrast to Western societies, more prone to interpreting the world in time terms, "American Indians hold their lands - places - as having the highest possible meaning, and all their statements are made with this reference point in mind" (Deloria 62). Connected to storytelling, the land is the source of tribal memory and it is crucial to apprehend the Native American articulation of history: "sacred stories are not something that happened long ago in a far-off place. They are alive and 
functioning in everyday life. This helps promote a feeling of love and connection with the land" (Gross 160).

Of the three interrelated meanings of land that Glen Coulthard defines"land-as-resource central to our material survival; land-as-identity, as constitutive of who we are as a people; and land-as-relationship" (62) — the second and third will be of the utmost relevance for my analysis. "The land, Aki, is both context and process" (Simpson 151); it is not simply "out there" but inextricably bound to all aspects of the self. People are "an inseparable part of an expansive system of interdependent relations covering the land and animals, past and future generations, as well as other people and communities" (Coulthard 63). Hence, the land provides an ethical framework of reciprocal relationship that Coulthard has theorized as "grounded normativity" (60), informed by "an intimate relationship to place" (Coulthard and Simpson 254). In this view, if humans meet their obligations to the land, animals, plants, and lakes, they will receive the same treatment, and their survival and well-being will be ensured (Coulthard 61). Thus, the land is "a mode of reciprocal relationship (which is itself informed by place-based practices and associated form of knowledge)" that should teach us how to live our lives "in relation to one another and our surroundings in a respectful, nondominating and nonexploitative way" (60). Expectedly, such a relationship to the land generates, Coulthard and Simpson claim, "the processes, practices and knowledges that inform our political systems," and to "willfully abandon them would amount to a form of auto-genocide" (254).

The land is also the main element of contention in settler colonialism, based on the occupation of indigenous territory and the transformation of the landscape to meet the colonists' demands. Space, "that ideologically inflected landscape produced by settler colonies" and its prime commodity (Mar and Edmonds 4), was imagined as available for appropriation, and once taken, racist structures and strategies are needed to keep it from the Indigenous peoples who try to get it back. In other words, dispossession is open-ended and it "integrates ongoing legal, social and political processes, many of which have a spatial dimension" (5). Hence, settler colonialism is precisely "a structure of domination that is partly predicated on the continuous dispossession of Indigenous peoples' lands and the forms of political authority and jurisdiction that govern our relationship to these lands" (Coulthard and Simpson 251). This process was largely successful: "Land and the organised spaces on it ... narrate the stories of colonisation" (Mar and Edmonds 2) which are "overwritten with European property claims" (10) on originally Indigenous places. But at the same time, settler colonialism 
is "unfinished business" (15), since "unsettling reminders of alternative and Indigenous claims to land remained ever present on the landscape" (4). ${ }^{1}$

This article engages with stories of colonization and stories of resistance written on the land in general and certain places in particular in Erdrich's novel. Key to my argument is the understanding of space as "storied space" (Johnson 113), an idea by no means exclusive to Native Americans but particularly relevant in this context. The intimate relation of places and stories is a feature of the storytelling traditions that is recovered in contemporary Native writing as a restoration of a language of self-expression and a vindication of sovereignty. If white supremacy is sustained on continued attacks on "the relationality of Indigenous political orders through the strategic targeting of Indigenous peoples' relationship to land," the response of Indigenous resistance and resurgence is "to protect Indigenous territories and to reconnect Indigenous bodies to land through the practices and forms of knowledge that these practices continuously regenerate" (Coulthard and Simpson 254). Writing is one of the ways to protect and reconnect to land, and a particularly effective one, as proved in novels like The Round House. ${ }^{2}$ The re-storying of space through writing that the novel exemplifies is also an act of mourning for lost lands and ways. Native grief for stolen land - similarly to the loss of lives, ceremonies and other aspects of their cultures-was disenfranchised, and this is at the root of American Indian historical trauma (Brave Heart and DeBruyn). As analyzed below, many of the places the protagonist of the novel connects to are grieving places, places to grieve and-according to the Anishinaabe understanding of the land, which assigns agency to all its elements-places which grieve, telling the stories of grief.

\footnotetext{
${ }^{1}$ The widely accepted contrast between space, a geographical abstraction, and place, connected to meaning, value, and stories, to community and affiliation (Buell 63-71) is not exactly applicable to the Native American context. Spiritual meaning is assigned to the land in general and to places in particular, so that both are the object of attachment. As a result of settler colonialism, Native Americans lost "both space and place, until remanded to federally defined spaces ('reservations') more like internment camps than decent substitutes for the pre-settlement home place or range" (64). If place is, in itself, a fragile and complex concept which opens up more issues than it lays to rest (62), referring to the idiosyncrasy of Native American reinscriptions of place in literature can be both challenging and productive, as I aim to prove in this essay.

${ }^{2}$ The relevance of place in Erdrich's novels, mostly set on a fictional reservation in North Dakota and its neighboring areas, has been addressed by many critics, who early on compared her creation to Faulkner's Yoknapatawpha. Her whole oeuvre can be read as a project of re-mapping place in connection to self and memory. So far, though, studies of The Round House have mostly focused on other issues of interest.
} 


\section{OVERWRITTEN BODIES, OVERWRITTEN LANDS}

The Round House is Louise Erdrich's fourteenth novel, and the second of "the justice trilogy" together with The Plague of Doves (2008) and LaRose (2016). Winner of the National Book Award, The Round House is a unique novel in Erdrich's oeuvre: its departure from the author's usual chorus of narrators and lyrical style underscores the novel's urgent purpose of denouncing the failure of justice for Native American rape victims. Set on an Ojibwe reservation in North Dakota over the course of a summer in the late 1980s, the novel is told from the adult perspective of thirteen-year-old Joe Coutts, whose mother Geraldine is violently raped and almost killed by a white man. ${ }^{3}$ This aggression takes place in the round house, a ceremonial log structure which Joe's ancestors built "to keep their people together and to ask for mercy from the Creator, since justice was so sketchily applied on earth" (315). When Joe's father Bazil, a tribal judge, fails to find justice for his wife, Joe sets out to solve the crime himself. In the end, Joe kills the rapist with the help of his friend Cappy, and the burden of this terrible act will mark the end of Joe's childhood.

The novel offers an abundance of images of bodies being written over as a result of the racist and sexist attack. Geraldine's face changes from being "puffed with welts and distorted to an ugly shape," "gray as ash" (10); to a sick green and indigo, with "[t]wo vertical lines, black as if drawn by a marker" that "creased her forehead" (23). Time after, "[d]eep violet streaks and the yellow of healing contusions still marred her face" (35) and although, to Joe's relief, "the knifelike mark between [his] mother's eyebrows" (305) eventually heals, some damage cannot be undone. The marks of the crime are written on Geraldine's family too: Bazil's face lines "deepened to cracks" with worry, and he "looked a thousand years old" (55), as if all the cases and conflicts were written on his face. As shown in the scene after the car accident in which Cappy is killed-where Joe's parents "walked in the door disguised as old people" (317), making the three of them face "the shock of that first moment when we all realized we were old" (317) - this summer's terrible experiences will remain written on their skins and spirits forever.

\footnotetext{
${ }^{3}$ The effective voice of Joe and his ethical dilemmas resonate with the voices of other first-person narrators in classic American novels, like Scout Finch - as suggested by various reviewers of the novel - as well as Huck Finn or Holden Caulfield, who share with Joe a sense of justice at odds with the adult world around them. Tharp, Bowers and Martínez-Falquina address the issue of violence against Native women in the novel.
} 
Nonetheless, the bodies and lives of the Anishinaabe are marked beyond this particular traumatic event. The very definition of tribal identity in connection to the land is overwritten by non-Native authorities, who indicate that a person should be called Indian "if their blood is just one quarter - it usually has to be from one tribe. But that tribe has also got to be federally recognized. In other words, being an Indian is in some ways a tangle of red tape" (30). This governmental categorization is imposed on people who are aware that "Indians know other Indians without the need for a federal pedigree, and this knowledge ... has nothing to do with government" (30). Settler colonial overwriting of Native space also affects legislation. Erdrich's text describes the reservation as "a legal limbo between competing jurisdictions" on a juxtaposition of state, tribal and fee land (Tharp 36). The fact that Geraldine cannot tell exactly where her rape occurred makes it extremely difficult to specify jurisdiction and apply justice. Bazil, the main representative of tribal law, has to confront the legal entanglement imposed on the reservation, which he illustrates for his son by tossing an old, stinking noodle casserole on the table, thrusting knives and forks in it to symbolize the most damaging cases that set precedent for the present situation (227-30). ${ }^{4}$

Defying imposed definitions of identity and legislation, Anishinaabe epistemologies and ontologies are recovered from the storytelling tradition, which functions as a palimpsest in the sense that it incorporates traditional stories as well as contemporary overwritings or re-storying acts. Realizing that no book can teach him what he needs, for "[t]here were no quotations in my father's repertoire for where we were" (307), Joe starts listening to the stories of Mooshum, an ancient man related to Anishinaabe trickster Nanapush. Joe learns the story of this trickster who saved his mother, falsely accused of being a wiindigoo or evil creature; or of Old Buffalo Woman, who gave Nanapush the instructions to build the round house and saved her people. Apart from assisting in sweatlodge ceremonies or attending the summer powwow with his friends, Joe further reconnects to the land and his Anishinaabe identity when, at Mooshum's suggestion, he goes on an improvised vision quest to seek the advice of the ajijaak or crane, his doodem. Also importantly, Bazil offers Joe an interpretation of the crime the boy has committed by connecting it to a traditional precedent: Bazil argues that Linden Lark meets the definition of a wiindigoo "and that with no other recourse, his killing fulfilled the requirements of a very old law" (306).

\footnotetext{
${ }^{4}$ Focusing on sovereignty and American Indian justice, Bauerkemper offers insightful views on the legal context, also explored by Castor, Ibarrola-Armendariz, or Tharp.
} 
By re-storying the rapist as a wiindigoo, his killing becomes "a wrong thing which serves an ideal justice," and "threads that unfair maze of land title law" by which the perpetrator could not be prosecuted (306). Hence, the tribe finds their way through that maze of injustice by becoming archaeologists of sorts, recovering stories and laws that lie under the surface.

\section{LAND-AS-RELATIONSHIP, LAND-AS-IDENTITY: RE-STORYING THE SELF}

Although the storytelling tradition provides the roots upon which contemporary Anishinaabe identity is sustained, neither Mooshum's stories nor wiindigoo laws can simply re-surface and replace the forms imposed by settler colonial processes. One reason is the persistence of unequal power relations in politics, economy or legislation; another is the fact that Native and non-Native voices are encoded in and defined by each other in this largely hybrid space so that they can only be understood in relation. The complexity of Joe's world is illustrated by the old reservation cemetery, a place full of stories and names, including the ones who died "too quickly in the years that surrounded the making of the reservation" (100). In Joe's words, "to be afraid of entering the cemetery by night was to fear not the loving ancestors who lay buried, but the gut kick of our history, which I was bracing to absorb. The old cemetery was filled with its complications" (100).

A useful concept to apprehend such complications of history is Sarah Dillon's use of the neologism "palimpsestuous" to characterize the structure derived from the process of layering that produces a palimpsest (4), to her, an "involuted phenomenon where otherwise unrelated texts are involved and entangled, intricately interwoven, interrupting and inhabiting each other" (245). The narrative structure of The Round House functions on the double principle of the palimpsestic - the more traditional view of the palimpsest as made of clearly defined layers that can be recovered ${ }^{5}$ - and the palimpsestuouswhich shows that the layers that make up a palimpsest are inherently related. These are respectively articulated as the archaeological focus on difference to vindicate sovereignty - illustrated by Michel Foucault's view of the historian's task as "the making visible of what was previously unseen" (Power 65) - and the acknowledgement of relationality akin to genealogy — considering that genealogy

\footnotetext{
${ }^{5}$ See, for example, Cooper Alarcón or Johannessen.
} 
"operates on a field of entangled and confused parchments, on documents that have been scratched over and recopied many times" (Foucault, "Nietzsche" 76).

The archaeological motif is prevalent in the novel: the lake near the round house brings to the surface clues connected to the crime-a gas can, a doll full of money, the car of another victim-names resurface to reconnect with one's ancestors; and the very novel is structured in layers, most notably, the most visible young detective narrative and the underlying history of racist and sexist violence. However, Joe painfully realizes that the task of recovering the past, of making his "before-mother" (89) return to him, will most likely prove impossible, for some things are simply irrecoverable: "I had believed that my real mother would emerge at some point.... But now it entered my head that this might not happen" (193). As he learns more about the perpetrator, the knowledge feels like "poison" in him (165), the antidote to which can only be found in Anishinaabe traditional stories: they teach him that we are not simply "in relationship with other people or things," but that "we are the relationships that we hold and are part of" (Wilson 80).

The idea of land-as-relationship is confirmed by observing his parents. Geraldine is a tribal enrolment expert in charge of files that register "the complicated branching and interbranching tangle of each bloodline," the "impenetrable undergrowth of names and liaisons" that makes the tribe (149):

At the tip of each branch of course the children are found, those newly enrolled by their parents, or often a single mother or father, with a named parent on the blank whose identity if known might shake the branches of the other trees. Children of incest, molestation, rape, adultery, fornication beyond reservation boundaries or within, children of white farmers, bankers, nuns, BIA superintendents, police, and priests. (149)

The potential danger of certain information should it come to the surface makes Geraldine keep the files locked in a safe with a secret combination, which gives Joe a view on the power of the connections within and beyond the reservation lines. Bazil's job is also associated to both archaeology and genealogy. For his research to find his wife's attacker, he digs in piles of apparently minor and unrelated old cases to register past behavior of and conflict between the people on and around the reservation. In the eyes of Joe, Bazil is convinced "that somewhere within his bench briefs, memos, summaries, and decisions lay the identity of the man whose act had nearly severed my mother's spirit from her body" (45). Clearly, the way to get to the story of what happened is the detective work of an archaeologist, of bringing what is hidden to the surface; but it is also, and very importantly so, a genealogical work of making the 
various discourses visible not as unities but "in their strategic connections" (Foucault, Power 38).

Because "Nishnaabeg conceptualizations of Aki are at their core profoundly relational" (Simpson 160), the understanding of identity as being-with should be rephrased as being-with-place. Relevant strategic connections are always located in place, and "[i]dentity for Indigenous peoples is grounded in their relationships with the land, with their ancestors who have returned to the land and with future generations who will come into being on the land" (Wilson 80). Accordingly, much of the narrative space in The Round House is devoted to Joe's development of a sense of self through acts of re-storying and reconnection to the land. The most relevant of these acts takes place in and around the round house, which accompanies the boy while he apprehends what happened to his mother: "As I climbed the hill, a breeze raised hairs on the back of my neck. But when I reached the round house, the sun fell like a warm hand on my shoulders" (59). The place is sacred but violated, a human-made construction with nature growing through its cracks. Joe knew "the general location of the crime," but not "the exact whereness of it" (60). Since the area is written over by jurisdictional lines, this lack of knowledge disempowers his family in the face of justice. Thus, Joe faces the fact that "[b]eing engaged in land as pedagogy as a life practice inevitably means coming face-to-face with settler colonial authority, surveillance, and violence (Simpson 166).

From his connection to the round house, Joe also learns that "[i]ntelligence flows through relationship between living entities" (Simpson 155): what he finds is not only a place to grieve - which the round house evidently is, enfranchising the pain of Joe, Geraldine, and the whole community - but also a place that grieves, a place with agency. The round house speaks to Joe in "a low moan of air," "a grieving cry [which] seemed emitted by the structure itself" (59); it "crie[s] out to [him] in [his] mother's anguished voice" (60). To use David Moore's words describing the work of Gerald Vizenor, "memory is woven with the ground as an equation of memory and matter to evoke the sense of presence and consciousness in matter, an animate universe speaking its stories" (99). In Erdrich's novel, the round house tells its own stories, voicing the grief of others as well as its own. Through the round house, Joe is connected to stories that he does not fully understand and which cannot be recovered in their totality. He later recalls how "the structure had cried out to me. I could see a part of something larger, an idea, a truth, but just a fragment. I could not see the whole, but just a shadow of that way of life" (215). Joe is in the presence of storied space, and the voices that were once heard here are 
still speaking. However, it is up to him to recover the fragments, the parts, and make a new whole which will no doubt be different from what has been lost, the old way of life written over by the forces of colonization.

In his process of recovering and connecting to stories and the land, Joe exemplifies the idea of grounded normativity, or the intimate, reciprocal relationship to place which is the basis of Indigenous existence. Often accompanied by a force that pulls him towards the earth, Joe illustrates that "[t]o be 'grounded' means to be in tune over time with the mind of a place" (Moore 96). In one scene, after a frustrating encounter with Geraldine, the boy sets himself to the task of planting his mother's garden and empties his anger into the ground: "We sifted out the old roots and dead stalks and broke up the clods so the earth was fluffy and fine. The dirt was moist deep down below the surface. Rich.... The ground drained my rage" (91). His connection to the ground is healing, but not romanticized: in the next scene, Joe confronts his father for not doing enough to catch the criminal, and the land reflects his sense of being trapped in an overwhelming web of emotions: "I had worked myself into a fury now, or planted myself into one with every puny hothouse plant that would not succeed in gaining my mother's attention.... A rough cloud had boiled over me" (93). Later, frustrated by his failing detective mission, Joe lies on the ground and feels "the earth pulling at [his] body," the gravity "draining [him] of strength" (95). The ground, which has a "seemingly infinite potency to absorb human pain" (Moore 98), takes in his frustration and feeds Joe with new spirit: "[t]he drawing flow of gravity suddenly reversed and I sat straight up, filled with an electric energy of purpose" (96). Soon after, the boy stands "rooted" (98), he puts his back against a tree and leans there, absorbing its power: "I was filled with that odd energy. I was allowing the tree to help me think" (98). All in all, the strengthening of Joe's connection to the land functions like a ceremony. As Wilson sees it, both "[t]he space and therefore the relationship between people or between people and their environment" are sacred concepts; "By reducing the space between things, we are strengthening the relationship that they share. And this bringing things together so that they share the same space is what ceremony is about" (87). 


\section{4. "I DIDN'T SEE A THING OUT OF PLACE...}

\section{DIDN'T SEE A THING IN PLACE”: TRICKSTER MAPS OF SOVEREIGNTY}

Mostly riding his bike, alone or accompanied by his friends, Joe is constantly on the move and he covers roads and paths within and beyond the reservation: he looks for clues here and there, visits relatives who feed him and tell him stories, works at the gas station and speaks to the customers, moves in with his uncle and aunt, steals a car to take Cappy to his girlfriend, rides back in his parents' car after the tragic end of this adventure, passing by the ice cream place that marked their return home in the before of their lives. Joe's journey is a sort of ceremonial hero's quest that echoes that of Nanapush, the Anishinaabe trickster of Mooshum's stories:

The silence of wind around us, the car cutting through the night along the Milk River, where Mooshum had once hunted, driven out farther and farther into the west, where Nanapush had seen buffalo straight back to the horizon, and then the next year not a single one. And after that Mooshum's family had turned back and taken land on the reservation. He'd met Nanapush there and together they had built the round house, the sleeping woman, the unkillable mother, the old lady buffalo. (315)

In his reconnection to the storied places in the novel, Joe writes a reservation "deeper map," to use Linda Hogan's phrase: this is a kind of Indigenous mapmaking practice "that recognizes the importance of narratives" (Johnson 114), for the deeper maps "must be read by the light of stories" (116). Clearly, any act of mapping is political and in the case of Indigenous peoples in a settler colonial space, it involves a resistance against the imposed stories of the conquerors. Joe is painfully aware that the lines written on the reservation-most evidently, the lines that mark jurisdiction and hinder justice-may be invisible but powerful, and they cannot simply be erased. Nonetheless, being written over does not mean renouncing agency; on the contrary, "[a]s many Native nations assert their inherent sovereignty, they insist on controlling their own territory and thus seek to map it through the use of their own nation-specific conventions" (Johnson 105). In other words, as Erdrich re-maps the reservation and Anishinaabe identity, she is undertaking an act of Indigenous overwriting of them both on her own terms.

This act of re-mapping through words recovers the traditional way maps were made: "Indigenous North American mapmakers focused on the cultural significance of the topographical features" (Johnson 106). Thus, a place with cultural significance would be rendered larger than others, reflecting context and 
relationship. Erdrich makes the round house the great signifier of Anishinaabe culture and sovereignty. Associated to dreaming and vision quests, its ceremonial nature is reinforced by its circular shape, and it becomes the "sacred center at a particular place" that the vast majority of Indian tribal religions had:

This center enables the people to look out along the four dimensions and locate their lands, to relate all historical events within the confines of this particular land, and to accept responsibility for it. Regardless of what subsequently happens to the people, the sacred lands remain as permanent fixtures in their cultural or religious understanding. (Deloria 67)

Built by trickster Nanapush under the instructions of Old Buffalo Woman, the round house is intimately related to the tribe's traditions and their resistance to colonizing power. The most visible trickster in Erdrich's fiction is inspired by the traditional Anishinaabe teacher who, in the words of Leanne Simpson, "stories the land with a sharp criticality necessary for moving through the realm of the colonized into the dreamed reality of the decolonized, and for navigating the lived reality of having to engage with both at the same time" (163-64). Before 1978, when the American Indian Religious Freedom Act was enacted and the right to traditional worship was returned to the tribes, the people in this fictional reservation used the round house for their ceremonies but had to pretend they were reading the Bible. Whenever the priest or the BIA superintendent arrived, they put away their water drums, eagle feathers, medicine bags, birchbark scrolls and sacred pipes and took out their Bibles, always open at Ecclesiastes Chapter 1, verse 4, which reads: "One generation passeth away, and another generation cometh, but the earth abideth forever" (60). This tricksterlike overwriting of the biblical words vindicates the idea that, irrespective of the layers imposed on it-generations of people, sets of traditions or worldviews - the earth always remains, well rooted underneath.

Making the round house the place of the trickster means that things here are not exactly in or out of place: chaos and order become entangled, reversed, as seen when, looking for clues, Joe "didn't see a thing out of place..., or rather, since it was the woods and everything was out of place and wild, I didn't see a thing in place. A neatened area. Something that did not look or feel right" (59). Pointing to the unfinished nature of settler colonialism, this dynamic, multilayered place is an example of "resistance within the social margins of the settler colonial world beyond which Indigenous peoples were historically pushed" (Mar and Edmonds 16). The round house is an empowering site of resistance and resurgence, it is a marginal but central place which 
creates "'holes in the fabric' of settled landscapes ... that step beyond the binarisms of settler government-driven paradigms" (17). In other words, it is a site of sovereignty understood as both difference and relation.

\section{THE SELF IN PLACE AT HOME: IT IS ROUND}

Neither the round house nor the relational identity it contributes to articulating should be romanticized or even stabilized. Although Erdrich does not name the round house in Ojibwemowin, her characterization of the place reflects an element of the traditional language: "the verb-based language of the Anishinaabeg lacks adjectives. Instead, the use of verbs to describe things imbues those things with a dynamic life that is always open to change" (Gross 225). Thus, in the Anishinaabe context, the adjective "round" would be phrased as a verba variation of "waawiyeyaa," meaning "it is round, is circular" ("Round") emphasizing the idea, already suggested by its circular shape, that the place is open to ongoing change and renewal.

The round house is also a storied place of encounter of what Owens called "frontier space" and "territory": frontier space is unstable, multidirectional, hybridized, indeterminate; territory is a place of containment, clearly mapped, invented to control and subdue (26). As frontier space, the round house may be "a space of extreme contestation," and "the zone of the trickster" (26). However, as the analysis of this novel makes clear, the territory in opposition to which the round house stands is very much alive and well. The rapist's words to Geraldine might be easily discarded as a caricature of white man's anger, but they represent the force of the settler colonial power that he is trying to reaffirm with his terrible act, a deliberate violation of woman and community:

He said we have no standing under the law for a good reason and yet have continued to diminish the white man and to take his honor.... Things are the wrong way around, he said. But here in this place I make things the right way around for me. The strong should rule the weak. Instead of the weak the strong! It is the weak who pull down the strong. But I won't get caught. (161)

Geraldine survived, but not all assaulted women in Native America are that fortunate. In any case, for as long as it is necessary, Native Americans will "continue to resist this ideology of containment and insist upon the freedom to reimagine themselves within a fluid, always shifting frontier space" (Owens 27). This reimagination may take different forms, but it will most surely include 
a re-storying of self in place. To borrow Sinclair and Cariou's words about a different work of art, this novel is an instance of Native creativity aimed at "the creation of a respectful and dignified home":

It involves creating a place full of possibility, built through sustainability and equitable relationships involving people, animals, spirits, and the landscape. It involves being honest with one's history, truth-telling, and talking about the complicated parts-even if that inspires discomfort and disagreement.... It involves constant motion, eternal change, and a commitment to balance, cooperation, and mutual responsibility. It involves acknowledging that life is complex, that it is all around us, and that we are a part of it. (4)

Contributing to the creation of such a home, The Round House functions as a palimpsest where the colonial and the decolonial, the overwritten and the overwriting, are all recognized in their individuality, only to be immediately acknowledged as part of and in relation to a larger whole. At the junction of colonial territory and frontier space, places are re-enfranchised, agency is restored, and grieving places struggle to become sovereign places.

\section{WORKS CITED}

Bauerkemper, Joseph. "Literary Realities: Trans/National Networks and Tribal Courts." The Native American Literature Symposium, Isleta Resort \& Casino, Albuquerque, NM, 19 Mar. 2016.

Bowers, Maggie Ann. "Literary Activism and Violence against Native North American Women." Wasafiri, vol. 90, June 2017, pp. 48-53.

Brave Heart, Maria Yellow Horse, and Lemyra M. DeBruyn. "The American Indian Holocaust: Healing Historical Unresolved Grief." American Indian and Alaska Native Mental Health Research, vol. 8, no. 2, 1998, pp. 56-78.

Breinig, Helmbrecht. "Transculturality and Transdifference: The Case of Native America." Transatlantic Voices: Interpretations of Native North American Literatures, edited by Elvira Pulitano, U of Nebraska P, 2007, pp. 44-62.

Breinig, Helmbrecht, and Klaus Lösch. "Transdifference.” Journal for the Study of British Cultures, vol. 13, no. 2, 2006, pp. 105-22.

Buell, Lawrence. The Future of Environmental Criticism: Environmental Crisis and Literary Imagination, Blackwell, 2005.

Castor, Laura. "Louise Erdrich's The Round House: Restorative Justice in a Coming of Age Thriller." Nordlit, vol. 40, 2018, pp. 31-49.

Cooper Alarcón, Daniel. "The Aztec Palimpsest: Toward a New Understanding of Aztlán, Cultural Identity and History." Aztlán: A Journal of Chicano Studies, vol. 19, no. 2, 1988-90, pp. 33-68.

Coulthard, Glen. Red Skins, White Masks: Rejecting the Colonial Politics of Recognition, U of Minnesota P, 2014. 
Coulthard, Glen, and Leanne Betasamosake Simpson. "Grounded Normativity/Place-Based Solidarity." American Quarterly, vol. 68, no. 2, 2016, pp. 249-55.

Deloria, Vine, Jr. God is Red: A Native View of Religion. Fulcrum, 1994.

Dillon, Sarah. The Palimpsest: Literature, Criticism, Theory. Bloomsbury, 2007.

Erdrich, Louise. LaRose. Corsair, 2016.

Erdrich, Louise. The Plague of Doves. HarperCollins, 2008.

Erdrich, Louise. The Round House. HarperCollins, 2012.

Foucault, Michel. "Nietzsche, Genealogy, History." The Foucault Reader, edited by Paul Rabinow, Pantheon, 1984, pp.76-100.

Foucault, Michel. Power/Knowledge: Selected Interviews and Other Writings 1972-1977, edited by Colin Gordon, Longman, 1980.

Gross, Lawrence W. Anishinaabe Ways of Knowing and Being. Routledge, 2014.

Henry, Gordon. “Anishinaabeskinuk: Writing Over Skins, Writing Over Imagi (natives).” Wasafiri, vol. 90, June 2017, pp. 32-40.

Ibarrola-Armendariz, Aitor. "Negotiating Traumatic Memories in Louise Erdrich's The Round House: White Man's Law vs. Native Justice and Tradition." Memory Frictions in Contemporary Literature, edited by María Jesús Martínez-Alfaro and Silvia Pellicer-Ortín, Palgrave Macmillan, 2017, pp. 255-76.

Johannessen, Lene M. "Palimpsest and Hybridity in Postcolonial Writing." The Cambridge History of Postcolonial Literature, edited by Ato Quayson, vol. 2, Cambridge UP, 2012, pp. 869-902. DOI:10.1017/CHOL9781107007031.008.

Johnson, Kelli Lyon. "Writing Deeper Maps: Mapmaking, Local Indigenous Knowledges, and Literary Nationalism in Native Women's Writing." Studies in American Indian Literatures, vol. 19, no. 4, 2007, pp. 103-20.

Mar, Tracey Banivanua, and Penelope Edmonds. "Introduction: Making Space in Settler Colonies." Making Settler Colonial Space: Perspectives on Race, Place and Identity, edited by Tracey Banivanua Mar and Penelope Edmonds, Palgrave Macmillan, 2010, pp. 1-24.

Martínez-Falquina, Silvia. "My Body Not My Own: An Intersectional View on Relationality in Fiction by Toni Morrison and Louise Erdrich.” Lectora: revista de dones i textualitat, vol. 26, 2020, pp. 117-32. DOI:10.1344/Lectora2020.26.8.

Moore, David. "The Ground of Memory: Vizenor, Land, Language." Native American Survivance, Memory, and Futurity: The Gerald Vizenor Continuum, edited by Birgit Däwes and Alexandra Hauke, Routledge, 2017, pp. 90-101.

"Round." Ojibwe People's Dictionary, ojibwe.lib.umn.edu/search?utf8=\%E2\%9C\%93\&q=round\& commit=Search\&type=english. Accessed 30 Apr. 2020.

Owens, Louis. Mixedblood Messages: Literature, Film, Family, Place. U of Oklahoma P, 2001.

Simpson, Leanne Betasamosake. As We Have Always Done: Indigenous Freedom through Radical Resistance. U of Minnesota P, 2017.

Sinclair, Niigaanwewidam James, and Warren Cariou, editors. Introduction. Manitowapow: Aboriginal Writings from the Land of Water, Highwater, 2011, pp. 1-12.

Tharp, Julie. "Erdrich's Crusade: Sexual Violence in The Round House." Studies in American Indian Literatures, vol. 26, no. 3, 2014, pp. 25-40.

Wilson, Shawn. Research Is Ceremony: Indigenous Research Methods. Fernwood, 2008. 


\section{PRZESTRZENIE ŻAŁOBY, PRZESTRZENIE AUTONOMII: PRZESTRZEŃ OPOWIEŚCI W THE ROUND HOUSE LOUISE ERDRICH}

\section{Streszczenie}

Artykuł jest przyczynkiem do debaty na temat odrodzenia rdzennych Amerykanów w kontekście kolonialnego wywłaszczenia i wykorzenienia. Jest odpowiedzią na potrzebę wyjścia poza uproszczone reprezentacje rdzennych Amerykanów i ich ziemi. Sposobem na to może być uznanie powiązania pomiędzy tożsamością rozumianą jako bycie-w-ziemi a zakorzenioną normatywnością. Artykuł analizuje powieść The Round House (2012) autorstwa Louise Erdrich z plemienia Anishinaabe, koncentrując się na symbolice, opisach i tematyce powiązanych z ponownym opowiadaniem tożsamości i ziemi rdzennych Amerykanów. Te elementy czynią z powieści dekolonizujący palimpsest złożony z odrębnych, lecz misternie powiązanych warstw. Esej dowodzi, że powieść Erdrich za pomocą słów kreśli nową mapę Ameryki, na której jej rdzenni mieszkańcy odzyskują swą podmiotowość i prawo do żalu. Ponadto The Round House zauważa złożone powiązania pomiędzy rdzennymi Amerykanami a stylem życia kolonialnych najeźdźców i redefiniuje pojęcie suwerenności.

Słowa kluczowe: literatura rdzennych Amerykanów; odrodzenie; palimpsest; ziemia-jako-tożsamość; ziemia-jako-relacja. 